\title{
IMPACT OF FUNGICIDE APPLICATIONS FOR LATE BLIGHT MANAGEMENT ON HUCKLEBERRY YIELDS IN CAMEROON
}

\author{
D.A. FONTEM, A.T. SONGWALANG, J.E. BERINYUY and R.R. SCHIPPERS ${ }^{1}$ \\ Faculty of Agriculture, University of Dschang, Box 208, Dschang, Cameroon \\ ${ }^{1}$ Horticultural Development Services LLP, 19 Travertine Road, Chatham, Kent ME5 9LQ, UK
}

(Received 26 October, 2002; accepted 9 April, 2003)

\begin{abstract}
The influence of late blight infections, caused by Phytophthora infestans, was evaluated on thirteen huckleberry (Solanum scabrum) varieties during the 2000 and 2001 cropping seasons in Dschang, Cameroon. A randomised split block design was used. Plants were sprayed four times with Ridomil Plus ${ }^{\otimes}$ (12\% metalaxyl $+60 \%$ cuprous oxide) at $2.5 \mathrm{~kg} \mathrm{ha}^{-1}$ on a 21 -day schedule while control plots were not sprayed. Late blight intensity was recorded weekly and fresh shoot yields were evaluated six times at 14-day intervals. Fungicide applications significantly reduced late blight intensity and consequently increased huckleberry yields. Cumulative shoot yields varied with the variety and fungicide treatment, from 54.14 to $238.33 \mathrm{t} \mathrm{ha}^{-1}$. Yield losses due to late blight infection were estimated at up to $46 \%$. Economic analyses indicated that fungicide sprays are necessary for a late blight protection programme in huckleberry. This spray regime based on fungicide application resulted in net profits of US\$ 694 to $\$ 8,467 \mathrm{ha}^{-1}$, depending on the variety used and the trial period. The results show that late blight infections if not controlled, decrease huckleberry yields, and consequently net farm incomes. High yielding resistant varieties or foliar applications of Ridomil Plus ${ }^{\oplus}$ may be incorporated in integrated pathogen management schemes against late blight in huckleberries with a view to minimise use of fungicides.
\end{abstract}

Key Words: Integrated management, Phytophthora infestans, Solanum scabrum, yield loss

\section{RÉSUMÉ}

L'influence du mildiou, causé par Phytophthora infestans, était évalué sur treize variétés de la morelle noire (Solanum scabrum) pendant les saisons culturalles de l'an 2000 et 2001 à Dschang, Cameroun. Les éssais étaient réalisés en split-blocs pris au hazard. Les plantes étaient traitées quatre fois avec Ridomil Plus (12\% de métalaxyl $+60 \%$ oxyde cuivreux) à 21 jours d'intervalle à la dose de $2.5 \mathrm{~kg} \mathrm{ha}^{-1}$. L'intensité du mildiou a été évalué hebdomadairement et les pousses fraiches ont été récoltées six fois à l'intervalle de 14 jours. Des traitements fongicides ont significativement réduit l'intensité du mildiou et par conséquent augmenté le rendement en pousses. Le rendement total en pousses fraiches a été variable. De 54, 14 à 238,33 t ha-1 ${ }^{-1}$, selon la variété et le traitement fongicide. Des pertes en rendements associées aux attaques du mildiou ont atteint $46 \%$. Des analyses économiques indiquent que quatre traitements au Ridomil plus"sont nécessaires dans un bon programme de protection de la morelle noire contre le mildiou. Ce régime de traitement a poduit des augmentations en revenu net de USS 694 à $8.467 \mathrm{ha}^{-1}$, selon la variété utilisée et la période d'essai. Des résultats indiquent que le mildiou peut baisser le rendement de la morelle noire et par conséquent le bénéfice net des planteurs de la morelle noire si les actions appropriées ne sont pas menées pour rayer les effets néfastes de cette maladie. En outre, l'utilisation des variétés résistantes ou des traitements foliaires au Ridomil plus" peut etre incorporée dans des programmes de lutte intégrée contre le mildiou de la morelle noire. 


\section{INTRODUCTION}

Solanum scabrum Miller, commonly called huckleberry or jamajama in Cameroon, is an important indigenous leafy vegetables in Africa (Schippers, 2000). The name huckleberry, may be confusing because the same name is also used for Gaylussacia baccata (Wangh.) K.Koch, a shrub with edible berries that belongs to the Ericaceae family (Schippers, 2002). Similarly, Solanum scabrum is often considered in literature as synonymous with other nightshades, such as $S$. americanum Miller and $S$. nigrum L. (Edmonds and Chweya, 1997; Schippers, 2002; Stevels, 1990).

Huckleberry is widely grown in more than 20 African countries, especially in the high rainfall areas of the humid forest zone of West and Central Africa and to a lesser extent in East Africa and is also found in southern Asia (Schippers, 1997; Schippers, 2000). It is the most commonly grown indigenous vegetable in Cameroon, and commercial fields are found mostly in the western and northwestern provinces of the country (Stevels, 1990; Westphal et al., 1981). In Cameroon, huckleberry is exported to neighbouring countries, such as Gabon and Nigeria (Schippers and Fereday, 1998).

Leaves and fresh shoots are used widely as a cooked vegetable and are often referred to as spinach. The spinach can be served with corn $f u f u$, plantains, sweetpotatoes, potatoes, yams, maize or pounded cocoyams (Ngundam, 1997). Huckleberry also has some medicinal value in certain parts of Africa and the juice extracts of the leaves are used to treat diarrhoea in children, certain eye infections, jaundice, sores and stomachaches (Dupriez and De Leener 1989; Edmonds and Chweya 1977; Kokwaro 1976, Maundu et al.,1999; Watt and Breyer-Brandwijk, 1962).

A major constraint to increased huckleberry cultivation in Cameroon is the susceptibility of the crop to diseases (Fontem, 1991a; Nkengakah, 2000; Schippers, 2000) among which is late blight, caused by Phytophthora infestans (Mont.) de Bary. A germplasm collection programme was carried out during 1.998 and 1999 to characterise the major accessions found in Cameroon (Berinyuy etal.,2002). The collection established about 13 morphologically distinct varieties. The response of these varieties to late blight infection is largely unknown. The present study was conducted to assess the effect of late blight on fresh shoot yields of various varieties of this vegetable and to evaluate the economic efficiency of fungicidal management of the disease with fortnightly applications of Ridomil Plus ${ }^{\circledR}(12 \%$ metalaxyl $+60 \%$ cuprous oxide)

\section{MATERIALS AND METHODS}

Cultural procedure. Field experiments were conducted during the 2000 and 2001 growing seasons in Dschang (1400 m), Cameroon. The land used in each cropping season had not been grown with any Solanaceous crop for the past four years. In each season, a randomised split block design was used with three replicates. Varieties were assigned to main plots while fungicide treatments occupied: sub-plots. "Each sub-plot, measuring $3.6 \times 2.5 \mathrm{~m}$, was separated by a cropfree zone $2 \mathrm{~m}$ wide to limit interplot interference.

Thirteen morphologically distinct huckleberry varieties were used in both seasons (Table 1). A nursery bed, measuring $16 \times 1.5 \mathrm{~m}$, was fertilised with $300 \mathrm{~kg} \mathrm{ha}^{-1}$ of urea to accelerate plant growth. The nursery was set 19 March 2000 and 9 April 2001 and seeds were drilled $5 \mathrm{~cm}$ apart in rows spaced $10 \mathrm{~cm}$. After sowing, the beds were shaded with fresh grass mulch until germination was completed. Nursery plants received two foliar sprays of maneb (Trimangol $8072 \mathrm{WP}$ ) at $1.6 \mathrm{~kg}$ a.i. ha ${ }^{-1}$ before transplanting.

Seedlings were transplanted when nursery plants were $20-30 \mathrm{~cm}$ high and had developed at least $5-6$ true leaves. They were planted in rows spaced $0.40 \mathrm{~m}$ apart with $0.25 \mathrm{~m}$ between plants within the row. In both seasons, field plots were fertilised with $120 \mathrm{~kg} \mathrm{ha}^{-1}$ of 20-10-10 (N-P-K) 7 and 49 days after transplanting (DAT). In the following year, plarts received a supplementary application of manure $\left(10 \mathrm{t} \mathrm{ha}^{-1}\right)$ before transplanting and a foliar fertiliser (Manvert 8-8$6 \mathrm{NPK}, 4 \mathrm{~L} \mathrm{ha}^{-1}$ ) at $38 \mathrm{DAT}$. In both seasons, plants were sprayed with deltamethrin (Decis 25 EC) at $0.7 \mathrm{~L} \mathrm{ha}^{-1}$ to control foliar insects, such as black aphids (Aphis fabae Scop.) and flea beetles (Epilachna hirta). The field was hand weeded and tilled as needed. 
Fungicide protection. In both trials, half of each main plot received four foliar sprays of Ridomil $\mathrm{Plus}^{\oplus}(72 \mathrm{WP})$ at $2.5 \mathrm{~kg} \mathrm{ha}^{-1}$ to control late blight infections, while the other half was not sprayed. A $3 \times 2.5 \mathrm{~m}$ bamboo sheet was held between each sprayed and unsprayed sub-plot during spraying to prevent drift of the fungicide onto unsprayed plants. The fungicide protection was applied using a Solo knapsack sprayer (Solo Kleinmotoren $\mathrm{GmbH}$, Sindelfingen, Germany) with a single flat fan nozzle that delivers about $700 \mathrm{~L} \mathrm{ha}^{-1}$ at a maximum pressure of $4 \mathrm{~kg} \mathrm{~cm}^{-2}$. The first treatment was applied at first sign of foliar late blight symptoms (14 DAT in 2000 and 20DAT in 2001) and a 21-day spray schedule was observed for subsequent sprays.

Disease and yield evaluations. Crops were exposed to naturally occurring inocula in the field. In both seasons, disease severity (percent of leaf area diseased) was scored weekly on five randomly selected plants in the centre rows of each sub-plot with the aid of a modified HorsfallBarratt (Berger, 1980) rating scale. In each season, thirteen weekly ratings, initiated from first foliar late blight symptoms, were scored for each subplot. Values for Standardised Area Under DiseaseProgress Curves (SAUDPC) were calculated from the severity data according to the formula used by Campbell and Madden (1990).

Plots were harvested six times on a 14-day s.hedule, starting from 35 DAT in 2000 and 27
DAT in 2001. Fresh shoots were handpicked from the inner rows of each plot. After discarding diseased leaves and foreign bodies, such as weeds and slugs, clean shoots were weighed and marketable yields were expressed for each subplot in metric tonnes fresh wt ha ${ }^{-1}$. Cumulative yields were obtained from the six harvests in each season.

\section{Economic appraisal of fungicide protection.}

Economic analyses were conducted for costs and returns to the fungicidal treatments on each variety. Total returns were the value of the marketable yields obtained in each sub-plot. A unit farm gate price of US $\$ 0.10 \mathrm{~kg}^{-1}$ of fresh huckleberry was applied on marketable yields to estimate the total returns. The cost of the fungicide used per hectare was US $\$ 50 \mathrm{ha}^{-1}$ for each treatment and the cost of spraying the fungicide was estimated at US\$ 7 $\mathrm{ha}^{-1}$. The total cost of fungicide application for one hectare of huckleberry was US $\$ 228$ per season.

The increase in leaf yield over unprotected (control) treatments was assumed to be solely due to the fungicide treatments. Therefore, partial budgeting was used to estimate profit per hectare for each huckleberry variety. Profit was estimated by deducting total fungicide control cost from income derived from yield increase above unsprayed treatments for each variety. Costs of land preparation, nursery maintenance, transplantation, weeding, insects control and harvesting were not included in the partial

- $\triangle B L E$ 1. Morphological characteristics of the varieties used in the study

\begin{tabular}{|c|c|c|c|c|c|}
\hline \multirow[t]{2}{*}{$\therefore$ ariety } & \multicolumn{2}{|c|}{ Leaf blade characteristics } & \multirow[t]{2}{*}{ Stem wings ${ }^{*}$} & \multirow[t]{2}{*}{ Stem and branch colour } & \multirow[t]{2}{*}{ Corolla colour } \\
\hline & Mean size $(\mathrm{cm})$ & Type & & & \\
\hline ミミว1 & $5.1 \times 6.6$ & Small & - & Purple & White \\
\hline$\Xi \Sigma \supset 2.1$ & $4.2 \times 5.5$ & Small & - & Green & Violet stripe \\
\hline$\equiv \equiv 24.2$ & $14.0 \times 22.0$ & Large & + & Green & Violet stripe \\
\hline$\equiv \Xi 55.1$ & $11.0 \times 13.0$ & Large & + & Green & White \\
\hline$\equiv \Xi 35$ & $4.3 \times 5.3$ & Small & - & Green & Purple \\
\hline$\Xi ミ 38$ & $9.1 \times 14.0$ & Medium & + & Green & White \\
\hline$\Xi \Xi: 9$ & $10.0 \times 13.0$ & Large & + & Purple & Purple \\
\hline$\Xi \Sigma: 3$ & $5.1 \times 5.9$ & Small & + & Green & Purple \\
\hline$\equiv \equiv 55$ & $6.7 \times 10.0$ & Medium & - & Green & Violet stripe \\
\hline इミ- 8 & $16.0 \times 18.0$ & Large & + & Green & Purple \\
\hline$\equiv \Xi-9$ & $7.2 \times 12.0$ & Medium & + & Purplish green & Purple stripe \\
\hline$\vdots \equiv \geq 2$ & $11.0 \times 15.0$ & Medium & + & Green & Violet strip \\
\hline$\Sigma \Sigma \Sigma 5.1$ & $8.6 \times 13.0$ & Medium & + & Purple & White stripe \\
\hline
\end{tabular}


between 5.07 and $47.13 \mathrm{tha}^{-1}$ (Table 3 ). The yields increased from the first to the third harvest in 2000 and the fourth harvest in 2001 . Except for the first harvest of 2001, all the yield estimates recorded in sprayed plots were significantly higher than those in unsprayed plots. Mean percent yield reduction varied between 8 and $44 \%$, depending on the harvest period and season. The highest yield loss was recorded during the third harvest period in both years (Table 3 ).

Cumulative yields were significantly higher in 2001 than in the preceding year, presumably due to the extra fertilization applied on the crop during the latter year. In 2000, the yields varied between 54.14 and $173.20 \mathrm{t} \mathrm{ha}^{-1}$ for unsprayed plots and between 64.59 and $225.62 \mathrm{t} \mathrm{ha}^{-1}$ for sprayed subplots. In the following year, the yields were higher, ranging from 95.83 to $191.33 \mathrm{tha}^{-1}$ for unsprayed sub-plots and from 114.44 to $238.33 \mathrm{t} \mathrm{ha}^{-1}$ for sprayed plots (Table 4).

Varieties varied in their response to the fungicide treatments. All the sprayed plots recorded increases in fresh shoot yields compared to the unsprayed plots. However, the yield increases were not significant $(\mathrm{P}>0.05)$ for late blight resistant varietics SS01, SS02.1, SS09, SS 13 and SS19 in 2000 and SS01, SS09, SS13 and SS19 in 2001 (Table 3 ). In 2000, the highest yielding variety in unsprayed sub-plots was the large leaf-type SSO9 $\left(1^{-3} 3.20 \mathrm{tha}^{-1}\right)$, followed by the large leaf-type SS18 (161.03 $\left.\mathrm{tha}^{-1}\right)$. In the following year, the highest yielding variety in unsprayed sub-plots was the medium leaf-type SS25.1 (191.33 $\left.\mathrm{t} \mathrm{ha}^{-1}\right)$, followed by the small leaf-type SS02.1 (149.17t ha $^{-1}$ ) (Table 4). Percent yield reduction varied between 5 and $45 \%$ in 2000 and 16 to $46 \%$ in 2001. A mean yield loss recorded for the 13 varieties was $26 \%$ in 2000 and $30 \%$ in 2001 . The highest yield loss was recorded on the most susceptible variety SS15 (45\% in 2000 and $46 \%$ in 2001) (Table 4).

\section{Economic feasibility of fungicide management.}

Results of economic feasibility of fungicide management are presented in Table 5. Mean returns for unsprayed plots were US $\$ 9,761$ in 2000 and US $\$ 12,558$ in 2001 . The returns derived from late blight protection were higher in sprayed than in the unsprayed plots. The mean values for sprayed plots were US\$13,252 in 2000 and US\$ 17,855 in 2001 . Total returns were higher for 2001 than for 2000 because of the higher yields recorded for the former that were presumably due to the application of more fertilisation. In 2000 , net profits were highest for the large leaf-type SS18 (US\$6,231), while in the following year, they were highest for the medium leaf-type SS 15 (US\$ 8,467). Profits derived from fungicide protection varied from US\$ 694 to 6,231 in 2000 and from US\$ 1,549 to US $\$ 8,467$ in 2001 . The mean profit for the 13 varieties was US $\$ 3,263$ in 2000 and US\$ 5,069 in 2001 (Table 5).

Benefit-cost ratios calculated for the 13 varieties generally ranged from 3.0 to 27.3 in 2000 and 6.8 to 37.1 in 2001 . The ratios were generally higher for late blight-susceptible varieties (SS04.2,

TABLE 3. Mean fresh shoot yields ( $t \mathrm{ha}^{-1}$ ) for six harvests of huckleberry as influenced by fungicide treatments against late blight during two seasons in Dschang, Cameroon

\begin{tabular}{|c|c|c|c|c|c|c|}
\hline \multirow[t]{2}{*}{ Harvest period } & \multicolumn{3}{|c|}{2000} & \multicolumn{3}{|c|}{2001} \\
\hline & Unsprayed & Sprayed & $\%$ yield reduction & Unsprayed & Sprayed & $\%$ yield reduction \\
\hline 1 & $12.59 b^{z}$ & $18.07 \mathrm{a}$ & 30 & $9.53 a$ & $10.35 a$ & 8 \\
\hline 2 & $17.28 \mathrm{~b}$ & 22.36 a & 23 & $13.69 \mathrm{~b}$ & 24.27 a & 44 \\
\hline 3 & $30.68 \mathrm{~b}$ & 44.89 a & 32 & $18.62 \mathrm{~b}$ & $31.93 \mathrm{a}$ & 42 \\
\hline 4 & $22.10 \mathrm{~b}$ & 27.62 a & 20 & $34.24 \mathrm{~b}$ & $47.13 \mathrm{a}$ & 27 \\
\hline 5 & $9.89 \mathrm{~b}$ & $12.42 \mathrm{a}$ & 20 & $24.91 \mathrm{~b}$ & $32.81 \mathrm{a}$ & 24 \\
\hline 6 & $5.07 \mathrm{~b}$ & $7.16 \mathrm{a}$ & 29 & $24.59 \mathrm{~b}$ & $32.06 \mathrm{a}$ & 23 \\
\hline Mean & $16.27 \mathrm{~b}$ & $22.09 \mathrm{a}$ & 26 & $20.93 \mathrm{~b}$ & $29.76 \mathrm{a}$ & 30 \\
\hline
\end{tabular}

Mean yields for 13 varieties

ZMeans within a row for each year followed by different letters are significantly different according to Fisher's LSD $(P=0.05)$ 
SS05.1, SS06, SS08, SS15 and SS18) than for resistant varieties (SS01, SS02.1, SS09, SS13, SS19 and SS22, and SS25.1). The highest benefitcost ratio was recorded for SS18 (27.3) in 2000 and SS15 (37.1) in 2001 (Table 5).

\section{DISCUSSION}

Contrary to a popular belief that large leaf-type varieties of huckleberry are more susceptible to late blight than the small leaf-types (Nkengaka, 2000), we did not observe any correlation between late blight susceptibility and leaf size. Late blightresistant and -susceptible varieties were found among the three leaf types.

In our previous investigations, late blight had been reported as the most important production constraint in major Solanaceous vegetables, such as potato (Fontem, 1991b; Fontem, 1998; Fontem et al., 1998) and tomato (Fontem, 1993; Fontem et al., 1998) in Cameroon. Huckleberries have been produced for centuries in Cameroon without any threat from late blight. This disease was first reported on potato in Cameroon in 1954 (Russel, 1954) and on huckleberry in 1991 (Fontem, 1991a). Although this study reveals that late blight is an important disease of susceptible huckleberry varieties, its severity in the field was not as high as that observed for potato or tomato in Cameroon. Moreover, yield losses of up to $46 \%$ were also low compared to $71 \%$ for potato (Fontem et al, 1998; Fontem, 1998) and $100 \%$ for tomato (Fontem et al., 1998).

Fungicide applications significantly reduced late blight intensity and consequently increased fresh shoot yields in susceptible varieties. Ridomil Plus $^{\circledR}$ or Ridomil MZ (12\% metalaxyl $+60 \%$ mancozeb) has been reported to control late blight effectively in potatoes and tomatoes in Cameroon (Fontem and Aighewi, 1993; Fontem et al., 1996; Fontem et al., 1998; Fontem, 1998). Economic analyses revealed that four sprays of this fungicide at $2.5 \mathrm{~kg} \mathrm{ha}^{-1}$ on a 21-day schedule are necessary for an adequate late blight protection programme in huckleberry. This spray programme resulted in profits of US $\$ 694$ to 8,359 , depending on the variety and trial period. Benefit-cost ratios were higher for susceptible huckleberry varieties than for resistant varieties, suggesting that fungicide applications were more profitable in susceptible varieties than in resistant ones. The study also revealed that high-yielding resistant varieties, such

TABLE 4. Cumulative fresh shoot yields ( $t$ ha $a^{-1}$ ) of huckleberry as influenced by fungicide treatments against late blight during two seasons in Dschang, Cameroon

\begin{tabular}{|c|c|c|c|c|c|c|}
\hline \multirow[t]{2}{*}{ Variety } & \multicolumn{3}{|c|}{2000} & \multicolumn{3}{|c|}{2001} \\
\hline & Unsprayed & Sprayed & $\%$ yield reduction & Unsprayed & Sprayed & $\%$ yield reduction \\
\hline sso1 & $54.14 \mathrm{a}^{z}$ & $64.59 \mathrm{a}$ & 16 & $108.33 \mathrm{a}$ & $142.28 \mathrm{a}$ & 24 \\
\hline SS02.1 & $88.35 \mathrm{a}$ & $99.92 \mathrm{a}$ & 12 & $149.17 b$ & $212.83 a$ & 30 \\
\hline SS04.2 & $121.25 b$ & $148.62 \mathrm{a}$ & 18 & $145.09 \mathrm{~b}$ & $230.56 a$ & 37 \\
\hline SS05.1 & $104.61 \mathrm{~b}$ & $129.85 \mathrm{a}$ & 19 & $105.28 \mathrm{~b}$ & $182.08 a$ & 42 \\
\hline SSO6 & $94.20 \mathrm{~b}$ & $155.17 \mathrm{a}$ & 39 & $135.17 \mathrm{~b}$ & 193.33a & 30 \\
\hline SS08 & $96.28 \mathrm{~b}$ & $133.89 \mathrm{a}$ & 28 & $98.61 \mathrm{~b}$ & $144.44 a$ & 32 \\
\hline SSO9 & $173.20 \mathrm{a}$ & $182.95 \mathrm{a}$ & 5 & $132.78 \mathrm{a}$ & $168.89 a$ & 21 \\
\hline SS13 & $62.01 \mathrm{a}$ & $71.35 a$ & 13 & $95.83 a$ & $131.28 \mathrm{a}$ & 27 \\
\hline SS15 & $75.31 \mathrm{~b}$ & $136.25 \mathrm{a}$ & 45 & $100.83 \mathrm{~b}$ & $187.78 \mathrm{a}$ & 46 \\
\hline SS18 & $161.03 \mathrm{~b}$ & $225.62 \mathrm{a}$ & 29 & $143.22 \mathrm{~b}$ & $193.06 a$ & 26 \\
\hline SS19 & 64.07 a & $73.29 a$ & 13 & $96.67 a$ & $114.44 a$ & 16 \\
\hline SS22 & $91.16 \mathrm{~b}$ & $130.64 \mathrm{a}$ & 30 & $130.28 b$ & $181.81 \mathrm{a}$ & 28 \\
\hline SS25.1 & $143.35 \mathrm{~b}$ & 170.67 a & 16 & $191.33 b$ & $238.33 a$ & 20 \\
\hline Mean & 97.61 & 132.52 & 26 & 125.58 & 178.55 & 30 \\
\hline $\operatorname{LSD}(0.05)$ & \multirow{2}{*}{\multicolumn{2}{|c|}{$\begin{array}{c}13.25 \\
6.7\end{array}$}} & - & \multirow{2}{*}{\multicolumn{2}{|c|}{$\begin{array}{r}36.44 \\
12.7\end{array}$}} & - \\
\hline CV (\%) & & & & & & \\
\hline
\end{tabular}

Yields for six 14-day harvests

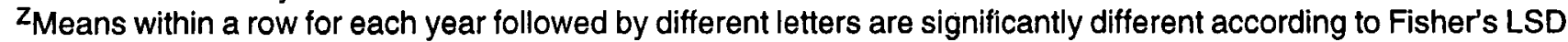
$(P=0.05)$ 
TABLE 5. Economic analyses for one hectare of huckleberry production under fungicide protection against late blight during two seasons in Dschang, Cameroon

\begin{tabular}{|c|c|c|c|c|c|c|c|c|}
\hline \multirow[t]{2}{*}{ Variety } & \multicolumn{4}{|c|}{2000} & \multicolumn{4}{|c|}{2001} \\
\hline & $\begin{array}{c}\text { TR for } \\
\text { unsprayed } \\
\text { subplots (a) }\end{array}$ & $\begin{array}{c}\text { TR for } \\
\text { sprayed } \\
\text { subplots (b) }\end{array}$ & $\begin{array}{l}\text { Profit(b- } \\
(a+228))\end{array}$ & $\begin{array}{c}\text { Benefit } \\
\text { - Cost } \\
\text { ratio* }\end{array}$ & $\begin{array}{c}\text { TR for } \\
\text { unsprayed } \\
\text { subplots (a) }\end{array}$ & $\begin{array}{l}\text { TR for } \\
\text { sprayed } \\
\text { subplots (b) }\end{array}$ & $\begin{array}{l}\text { Profit(b- } \\
(a+228))\end{array}$ & $\begin{array}{c}\text { Benefit } \\
- \text { Cost } \\
\text { ratio }\end{array}$ \\
\hline SS01 & 5,414 & 6,459 & 817 & 3.6 & 10,833 & 14.228 & 3,167 & 13.9 \\
\hline SS02.1 & 8,835 & 9,992 & 929 & 4.1 & 14,917 & 21,283 & 6,138 & 26.9 \\
\hline SS04.2 & 12,125 & 14,862 & 2,509 & 11.0 & 14,509 & 23,056 & 8,319 & 36.5 \\
\hline SS05.1 & 10,461 & 12,985 & 2,296 & 10.1 & 10,528 & 18,208 & 7,452 & 32.7 \\
\hline SS06 & 9,420 & 15,517 & 5,869 & 25.7 & 13,517 & 19,333 & 5,588 & 24.5 \\
\hline SS08 & 9,628 & 13,389 & 3,533 & 15.5 & 9.861 & 14,444 & 4,355 & 19.1 \\
\hline SSO9 & 17,320 & 18,295 & 975 & 4.3 & 13,278 & 16,889 & 3,383 & 14.8 \\
\hline SS13 & 6,201 & 7,135 & 706 & 3.1 & 9,583 & 13,128 & 3,317 & 14.5 \\
\hline SS15 & 7,531 & 13,625 & 5,866 & 25.7 & 10,083 & 18,778 & 8,467 & 37.1 \\
\hline SS18 & 16,103 & 22,562 & 6,231 & 27.3 & 14,322 & 19,306 & 4,756 & 20.9 \\
\hline SS19 & 6,407 & 7,329 & 694 & 3.0 & 9,667 & 11,444 & 1,549 & 6.8 \\
\hline SS22 & 9,116 & 13,064 & 3,720 & 16.3 & 13,028 & 18,181 & 4,925 & 21.6 \\
\hline SS25.1 & 14,335 & 17,067 & 2,504 & 11.0 & 19,133 & 23,833 & 4,472 & 19.6 \\
\hline Mean & 9.761 & 13.252 & 3263 & 14.3 & 12.558 & 17,855 & 5,069 & 22.3 \\
\hline
\end{tabular}

Economic returns for six 14-day harvests

All figures are in US $\$$ ha $^{-1}$ (US $\$ 1=750$ FCFA)

Total return (TR) is the value of yield $\left(\mathrm{kg} \mathrm{ha}^{-1} \times\right.$ US $\left.\$ 0.10 \mathrm{~kg}^{-1}\right)$

${ }^{*}$ Benefit-cost ratio was calculated as profit/cost

as SS09 and SS25.1, might be adopted by farmers to reduce any dependence on chemical fungicides.

These results show that huckleberry late blight infections may decrease fresh leaf yields and consequently net farm incomes if not checked by an appropriate management method. Besides, resistant varieties or foliar sprays of Ridomil Plus ${ }^{\circledR}$ may be incorporated into integrated pathogen management schemes against huckleberry late blight.

\section{ACKNOWLEDGEMENTS}

The authors are grateful to the Department for International Development (DFID) for funding this Competitive Research Facility project (R7025C) and the International Foundation for Science for providing supplementary support. This project was administered by the Asian Vegetable Research and Development Centre (AVRDC), based in Arusha, Tanzania, with technical support from the Natural Resources Institute (NRI). The authors thank Martin Nkobe for his valuable assistance.

\section{REFERENCES}

Berger, R.D. 1980. Measuring disease intensity. In:Proceedings of E.C. Stakman Commemorative Symposium on Crop Loss Assessment. Univ. of Minnesota Misc. Publ. 7, St Paul. pp. 28-31.

Berinyuy, J.E., Fontem, D.A., Focho, D.A. and Schippers, R.R. 2002. Morphological diversity of Solanum scabrum accessions in Cameroon. IPGRI Newsletter. (In Press).

Campbell, C.L. and Madden, L.V. 1990. Introduction to Plant Disease Epidemiology. John Wiley \& Sons, New York. 532pp.

Dupriez, H. and De Leener, P. 1989. African Gardens and Orchards, Growing Vegetables and Fruits. MacMillan Press, Ltd. London. 333pp.

Edmonds, J.M. and Chweya, J.A. 1997. Black nightshades. Solanum nigrum L. and related species. Promoting the conservation and use of underutilized and neglected crops. 15. Institute of Plant Genetics and Crop Plant Research, Gatersleben/IPGRI, Rome, Italy. 
Fontem, D.A. 1991a. AnInventory and Evaluation of Major Diseases of Vegetable Crops in Cameroon. Technical Report. University Centre of Dschang. 14pp.

Fontem, D.A. 1991b. An assessment of potato diseases in the western highlands of Cameroon. Biosciences Proceedings 2:82-86.

Fontem, D.A. 1993. Survey of tomato diseases in Cameroon. Tropicultura 11:87-90.

Fontem, D.A. and Aighewi, B. 1991. Effect of fungicides on late blight progress and yield of potato in the west province of Cameroon. In: Tropical Root Crops in a Developing Economy. Ofori, F. and Hahn, S.K. (Eds.), pp. 496-501. IITA, Ibadan, Nigeria.

Fontem, D.A. and Aighewi, B. 1993. Effect of fungicides on late blight control and yield loss of potato in the western highlands of Cameroon. International Journal of Pest Management 39:152-155.

Fontem, D.A., Nono-Womdim, R., Opena, R.T. and Gumedzoe, M.Y.D. 1996. Impact of early and late blight infections on tomato yield. TVIS Bulletin 1:7-8.

Fontem, D.A. 1998. Dynamics and Integrated Management of Potato Late Blight in Cameroon. PhD thesis, University of Benin, Lome. 161pp.

Fontem, D.A., Gumedzoe, M.Y.D. and NonoWomdim, R. 1998. Biological constraints in tomato production in the western highlands of Cameroon. Tropicultura 16:89-92.

Kokwaro, J.O. 1976. Medicinal plants of East Africa. East African Literature Bureau, Nairobi, Kampala, Dar-es-Salaam.

Maundu, P.M., Ngugi, G.W. and Kabuye, C.H.S. 1999. Traditional food plants of Kenya. Kenya Resource Centre for Indigenous Knowledge, National Museums of Kenya, Nairobi.270pp. Ngundam, C.F.P. 1997. The place of indigenous vegetables in the farming systems of Cameroon. In: African Indigenous Vegetables. Workshop Proceedings,January 13-18, 1977. Limbe, Cameroon. Schippers, R.R. and Budd, L. (Eds.), pp. 52-57, IPGRI Nairobi/NRI Kent.

Nkengakah, P. 2000. Inventory and assessment of major diseases of indigenous vegetables in
Foumbot. Mémoire de Maîtrise. Université de Dschang.

Russel, E.J. 1954. Potato blight in West Africa. Empire Journal of Experimental Agriculture 22:19-22.

Schippers, R.R. 1997. Domestication of indigenous vegetables for sub-Sahara Africa: a strategy paper. In: African Indigenous Vegetables. Workshop Proceedings. January 13-18, 1977. Limbe, Cameroon. Schippers, R.R. and Budd, L. (Eds.), pp. 125-154. IPGRI Nairobi/NRI Kent.

Schippers, R.R. 2000. African Indigenous Vegetables, an overview of the cultivated species. Chatham, U.K. Natural Resources Institute/ACP-EU Technical Centre for Agricultural and Rural Cooperation. pp. 176189.

Schippers, R.R. 2002. African Indigenous Vegetables, an overview of the cultivated species. Revised version on CD-Rom. Horticultural Development Services LLP and Natural Resources International, University of Greenwich, Chatham, U.K.

Schippers, R.R. and Fereday, N. 1998. Opportunities and constraints in the subsistence production and marketing of indigenous vegetables in East and Central Africa. NRI project report A0699. Joint report with Dschang University, IRAD and IITA in Cameroon, and Makerere University and Kawanda Agricultural Research Institute in Uganda. 53pp.

Stevels, J.M.C. 1990. Légumes traditionnels du Cameroun, une étude agro-botanique. Wageningen Agricultural University Papers No. 90-1. Wageningen, The Netherlands. 262pp.

Watt, J.M. and Breyer-Brandwijk, M.G. 1962. Solanum nigrum L. In: The Medicinal and Poisonous Plants of Southern and Eastern Africa. E. and S. Livingstone Ltd, Edinburg and London. pp. 996-1000.

Westphal, E., Embrechts, J., Mbouemboue, P. Mouzong, B. and Westphal-Stevels, J.M.C. 1981. L'Agriculture Autochtone au Cameroun. Misc. Papers 20. Landbouwhogeschool Wageningen. 175pp. 